\title{
The effect of a consumption-based accounting method in national GHG inventories: a trilateral trade system application
}

\author{
Simone Bastianoni ${ }^{1 *}$, Dario Caro ${ }^{1}$, Simone Borghesi ${ }^{2}$ and Federico Maria Pulselli ${ }^{1}$ \\ Ecodynamics Group, Department of Earth, Environmental and Physical Sciences, University of Siena, Siena, Italy \\ 2 Department of Political and International Sciences, University of Siena, Siena, Italy
}

\section{Edited by:}

Joni Jupesta, United Nations

University, Japan

\section{Reviewed by:}

Ramesh Lekshmana, Dr. MGR

Educational and Research Institute

University, India

Masaru Yarime, University of Tokyo,

Japan

${ }^{*}$ Correspondence:

Simone Bastianoni, Ecodynamics

Group, Department of Earth,

Environmental and Physical Sciences,

University of Siena, Pian dei

Mantellini 44, Siena 53100, Italy

e-mail: bastianoni@unisi.it
The allocation of emissions embodied in international trade is crucial to evaluate the real impact that each country has on climate change and its responsibility in greenhouse gas (GHG) emissions. In this paper, we develop a new theoretical framework recently proposed by Caro et al. (2014) that computes the carbon emissions embodied in international trade according to a consumption-based accounting. The method uses the value of the goods traded internationally and the respective carbon intensity as a coefficient of national efficiency. To provide an example of application of the proposed methodology and assess its difference with respect to the current producer-based GHG accounting, we analyze a trilateral trade system composed by three countries (Sweden, Italy, and Poland) with large differences in terms of carbon intensity (low, medium, and high carbon intensity, respectively). From the analysis of the data during the period 2000-2008, it emerges that the proposed consumption-based accounting would imply an increase of Italian and Swedish emission responsibility by 1.4 and $11.8 \%$, respectively, with respect to the conventional GHG accounting, and a decrease of the Polish responsibility by $2.81 \%$. To assess the possible consequences deriving from the application of this new methodology, we also consider the effects of a shift of the Italian imports from Poland to Sweden of Machinery and Transport Equipments, a crucial sector in the trade relations among the three countries, which accounts for about $45 \%$ of total exports from Poland and Sweden to Italy. Finally, we discuss some policy implications deriving from the application of the consumption-based accounting, devoting particular attention to the results emerging from its hypothetical adoption in the EU-27. The analysis performed in the paper suggests that the adoption of a consumption-based accounting could be an important tool in the climate change challenge to reduce global emissions.

Keywords: consumer responsibility, consumption-based accounting, carbon intensity, emissions embodied in international trade, GHG emissions

\section{INTRODUCTION}

The Intergovernmental Panel on Climate Change (IPCC) has defined a complete method to standardize the computation of greenhouse gas (GHG) emissions at national level. Currently, the monitoring of GHG emissions within a territorial system (country, region, etc.) uses IPCC guidelines to realize annual inventories assessing the amount of GHG released in the atmosphere (IPCC - Intergovernmental Panel on Climate Change, 2006). IPCC refers to the principle of geographical responsibility to allocate emissions: GHG emissions are in general assigned on the basis of the source localization. However, according to this principle, if a country imported all the goods that it consumes, it would have zero emissions (except those related to burning fossil fuels) (Bastianoni et al., 2004). Consequently, a real problem emerges for the allocation of emissions related to international trade. For instance, as pointed out by Andersen et al. (2010), if a car is produced in Japan and then exported in France, how should emissions be allocated: to Japan as producer country or France as the consumer country? This crucial choice determines the results of the GHG inventory and the related policy implications.

Several authors proposed alternative approaches to allocate GHG emissions (e.g., Gupta and Bhandari, 1999; Proops et al., 1999; Baer et al., 2000; Ferng, 2003; Rodrigues et al., 2006; Zaks et al., 2009). In particular, some authors have proposed allocation schemes in which carbon emissions are shared between producers and consumers (Shui and Harris, 2006; Lenzen et al., 2007; Andrew and Forgie, 2008; Rodrigues and Domingos, 2008). These studies have highlighted that production-based accounting does not take into account emissions connected with goods produced elsewhere but consumed within national boundaries, so that the full environmental footprint of a country may not be correctly assessed.

Consequently, the scientific community has focused on an alternative consumer perspective that could complement the geographical/producer-based one by including all driving forces 
for GHG emissions associated with consumption (Davis et al., 2011). In this regard, the environmentally extended input-output (EEIO) analysis has long been recognized as a useful tool for attributing GHG emissions or resource use to final demand (i.e., total consumptions by households, private and public national bodies, and government) in a consistent accounting framework (Wiedmann, 2009). Consumer-based GHG profiles estimated with EEIO models include, in monetary terms, imports as process vectors responsible for GHG emissions, as well as the indirect emissions in the total supply chain, assigning these to each consumer country as they directly solicit the production of imported goods and services. Recent contributions, either at the level of policy support or basic research, have attempted to overcome these methodological weaknesses and divergences with the development of international data gathering guidelines and IO manuals (e.g., Eurostat, 2011) as well as multi-regional input-output (MRIO) databases (Wiedmann et al., 2011).

By using EEIO and specific MRIO models, several authors provided important results (Li and Hewitt, 2008; Su et al., 2013). Munksgaard and Pedersen (2001) showed that the $\mathrm{CO}_{2}$ trade balance of Denmark has dramatically changed, turning into a deficit of seven million tonnes from a surplus of 0.5 million tonnes during the period 1989-1994. Consequently, it has become more difficult for Denmark to reach its national $\mathrm{CO}_{2}$ target as an increasing part of emissions generated on the Danish territory is caused by foreign demand. Peters and Hertwich (2008) determined the $\mathrm{CO}_{2}$ emissions embodied in international trade among 87 countries for the year 2001. They found that globally there are over $5.3 \mathrm{Gt}$ of $\mathrm{CO}_{2}$ embodied in trade and that Annex I countries are net importers of $\mathrm{CO}_{2}$ emissions. Davis and Caldeira (2010) calculated that, in 2004, 23\% of global $\mathrm{CO}_{2}$ emissions $\left(6.2 \mathrm{GtCO}_{2}\right)$ were traded internationally.

However, in a recent paper, Lenzen et al. (2012) argue that the adoption of EEIO when dealing with GHGs inventory in international agreements has been limited so far by a number of implementation issues: (i) EEIO models are labor-intensive; (ii) EEIO tables do not cover the entire world and are not always available as a long, continuous time series; (iii) currently, EEIO databases only provide results, without accompanying estimates of reliability and uncertainty. As a consequence, Caro et al. (2014) proposed a new emissions allocation method based on a consumer perspective called national carbon intensity (NCI) method. It is less detailed than the MRIO, as it does not use a specific carbon intensity for each sector and does not include indirect emissions; however, it is easy to apply, not labor-intensive to implement, and no further data is needed beyond those already available at the national level. Furthermore, a comparative analysis with MRIO models performed by Caro et al. (2014) showed that the NCI method gives, in general, a realistic picture of the emissions embodied in international trade and consequently of emissions due to consumption. In particular, comparing the results obtained using our method with those of the EEIO, the differences in terms of emission responsibility between the two methods were found to be below 5\% for most of the largest import/export countries (Caro et al., 2014).

In this work, we consider the effects of using the NCI method on the allocation of emissions responsibility. For this purpose, different from the previous contribution, we apply the NCI method to a three nation system, showing how the imports from countries with different emission intensity modify results for each nation with respect to the IPCC computation method. The trilateral trade system examined in the paper can provide a minimal model of a worldwide trade among three macro-areas. A further application at the single sector level is then introduced to discuss how a hypothetical change of trade partners induced by the NCI method would affect each country's emission responsibility. The structure of the paper is as follows. Section "Theoretical Framework" presents the NCI method adopted in the paper. Section "A Practical Application" introduces a practical application for three European countries and shows the results that emerge from this trilateral system. Section "Conclusion" discusses the policy implications that derive from the theoretical and practical analysis.

\section{THEORETICAL FRAMEWORK}

According to the NCI method (Caro et al., 2014), the responsibility of each country in terms of GHG emissions can be computed by adding to the traditional IPCC scheme (IPCC - Intergovernmental Panel on Climate Change, 2006) - which adopts a purely geographical criterion - the algebraic sum of the emissions embodied in imported goods minus those embodied in exported goods. The emission responsibility of each country can therefore be formally described as follows:

$$
R_{\mathrm{i}}=\mathrm{DE}_{\mathrm{i}}-g_{\mathrm{i}} \cdot X_{\mathrm{i}}+\sum_{\mathrm{k} \neq \mathrm{i}} g_{\mathrm{k}} \cdot M_{\mathrm{k}, \mathrm{i}}
$$

where $R_{\mathrm{i}}$ is the emission responsibility of country $\mathrm{i}, \mathrm{DE}_{\mathrm{i}}$ represents the Direct Emission generated inside country $i$, and actually recorded by the IPCC inventory, $g_{\mathrm{i}}$ is the carbon intensity of country i, i.e., the ratio of a country's GHG emissions to its GDP (expressed in tons of $\mathrm{CO}_{2}$ equivalents, hereafter referred as to $\mathrm{CO}_{2} \mathrm{e}$, divided by the national production level in monetary terms, see, e.g., Zhang, 2011), $X_{\mathrm{i}}$ is the country's exports in monetary terms, $M_{\mathrm{k}, \mathrm{i}}$ is the country's imports from k countries (rest of the world) in monetary terms and $g_{\mathrm{k}}$ is the carbon intensity of the $\mathrm{k}$ countries from which goods are imported.

Therefore $R_{\mathrm{i}}$ is equal to the emissions generated inside the country, minus the total emissions embodied on average in exported goods, plus the sum of all emissions generated outside the country associated to imported goods.

The term $-g_{\mathrm{i}} \cdot X_{\mathrm{i}}+\sum_{\mathrm{k} \neq \mathrm{i}} g_{\mathrm{k}} M_{\mathrm{k}, \mathrm{i}}$ represents the amount of emissions $\left(\mathrm{CO}_{2} \mathrm{e}\right)$ that should algebraically be added to each country's emission balance with respect to the results obtained by using national IPCC inventory. By applying the methodology to a trilateral system in this paper, we calculate emission responsibility $(R)$ for three generic countries (a, b, c) as follows (Eqs 2-4):

$$
\begin{aligned}
& R_{\mathrm{a}}= {\left[\mathrm{DE}_{\mathrm{a}}-\left(g_{\mathrm{a}} \cdot X_{\mathrm{a}-\mathrm{b}}\right)-\left(g_{\mathrm{a}} \cdot X_{\mathrm{a}-\mathrm{c}}\right)+\left(g_{\mathrm{c}} \cdot M_{\mathrm{c}-\mathrm{a}}\right)\right.} \\
&\left.+\left(g_{\mathrm{b}} \cdot M_{\mathrm{b}-\mathrm{a}}\right)\right] \\
& R_{\mathrm{b}}= {\left[\mathrm{DE}_{\mathrm{b}}-\left(g_{\mathrm{b}} \cdot X_{\mathrm{b}-\mathrm{a}}\right)-\left(g_{\mathrm{b}} \cdot X_{\mathrm{b}-\mathrm{c}}\right)+\left(g_{\mathrm{c}} \cdot M_{\mathrm{c}-\mathrm{b}}\right)\right.} \\
&\left.\quad+\left(g_{\mathrm{a}} \cdot M_{\mathrm{a}-\mathrm{b}}\right)\right] \\
& R_{\mathrm{c}}=\left[\mathrm{DE}_{\mathrm{c}}-\left(g_{\mathrm{c}} \cdot X_{\mathrm{c}-\mathrm{a}}\right)-\left(g_{\mathrm{c}} \cdot X_{\mathrm{c}-\mathrm{b}}\right)+\left(g_{\mathrm{b}} \cdot M_{\mathrm{b}-\mathrm{c}}\right)\right. \\
&\left.\quad+\left(g_{\mathrm{a}} \cdot M_{\mathrm{a}-\mathrm{c}}\right)\right]
\end{aligned}
$$


where, for example, $X_{\mathrm{a}-\mathrm{b}}$ indicates the exports from country "a" to country "b," whereas $M_{\mathrm{c}-\mathrm{a}}$ denotes the country "a" imports from country "c." Notice that it is obviously $X_{\mathrm{a}-\mathrm{b}}=M_{\mathrm{b}-\mathrm{a}}$. Also notice that this theoretical framework can be easily generalized to $n$ countries building up a matrix in order to compute the carbon emissions transferred from/to each nation through international trade.

According to Eqs 2-4, the responsibility assignment strongly depends on the carbon intensity factor. This means that importing goods from a country with high carbon intensity indirectly implies an increase of responsibility for the importer nation. If international agreements, policies, and sanction systems were accordingly modified to reflect the consumer responsibility, this would likely induce final consumers to stimulate the production of goods in countries with cleaner technologies and production processes, thus further enhancing the consequences of a shift from the production- to the consumption-based accounting.

In order to assess the possible consequence of the adoption of NCI method, let us assume that country "a" shifts its imports of a given good from country " $b$ " to country "c," and that such a shift is driven exclusively by the difference in the carbon intensity of these two exporter countries. More precisely, country " $c$ " is assumed to have a lower carbon intensity than country "b," so that country "a" is induced to purchase the goods from country " $c$ " in order to reduce its indirect responsibility.

The effect of this change in the trade dynamics on the emission responsibility of country "a" can be described as follows:

$$
\Delta R_{\mathrm{a}}=R_{\mathrm{a}}^{*}-R_{\mathrm{a}}=g_{\mathrm{b}} \cdot \Delta M_{\mathrm{b}-\mathrm{a}}+g_{\mathrm{c}} \cdot \Delta M_{\mathrm{c}-\mathrm{a}}
$$

where $R_{\mathrm{a}}^{*}$ is the responsibility of country "a" modified after the shift in imports from country "b" to country "c" (i.e., the star at the exponent indicates the new value of the variable $\mathrm{R}_{\mathrm{a}}$ after such a shift); $\Delta M_{\mathrm{b}-\mathrm{a}}=M_{\mathrm{b}-\mathrm{a}}^{*}-M_{\mathrm{b}-\mathrm{a}}<0$ is the reduction in the amount of imports of country "a" from country " $b$," whereas $\Delta M_{\mathrm{c}-\mathrm{a}}=M_{\mathrm{c}-\mathrm{a}}^{*}-M_{\mathrm{c}-\mathrm{a}}>0$ is the correspondent increase in the amount of imports of country "a" from country "c." For the sake of simplicity, in what follows, we will assume that the economic value of the goods previously imported from country " $b$ " is equal to that of the same goods that is now imported from country "c," that is: $\Delta M_{\mathrm{b}-\mathrm{a}}=\Delta M_{\mathrm{c}-\mathrm{a}}$.

\section{A PRACTICAL APPLICATION}

We illustrate a practical application of our theoretical framework by focusing on three countries: Italy, Poland, and Sweden. The choice of these countries is primarily due to the values of their carbon intensity, in the EU context: Sweden has one of the lowest carbon intensities within the EU, Poland has one of the highest, whereas Italy shows intermediate values between them (Eurostat, 2011). In addition, there are good commercial relations among all the three countries taken into account. We choose a 9-year period of analysis, from 2000 to 2008, just before the beginning of the global financial crisis. Data for import-export are taken from Eurostat (2011) (Table 1).

Eurostat provides also data on gross domestic product, GDP (Current prices-million euros), and GHG net emissions, the latter being collected from other institutions. We used these two data
Table 1 | Import-export among Italy, Poland, and Sweden during the period 2000-2008 (Eurostat data "EU-27 trade since 1988 by HS2-HS4"), million of Euro.

\begin{tabular}{|c|c|c|c|c|c|c|}
\hline & \multicolumn{2}{|c|}{ Italy } & \multicolumn{2}{|c|}{ Poland } & \multicolumn{2}{|c|}{ Sweden } \\
\hline & Poland & Sweden & Italy & Sweden & Italy & Poland \\
\hline 2000 export & 2089 & 3566 & 4405 & 1568 & 2230 & 939 \\
\hline 2000 import & 4405 & 2230 & 2089 & 939 & 3566 & 1568 \\
\hline 2001 export & 2199 & 2935 & 4624 & 1379 & 2157 & 1049 \\
\hline 2001 import & 4624 & 2157 & 2199 & 1049 & 2935 & 1379 \\
\hline 2002 export & 2395 & 3021 & 4888 & 1383 & 2310 & 1326 \\
\hline 2002 import & 4888 & 2310 & 2395 & 1326 & 3021 & 1383 \\
\hline 2003 export & 2694 & 3188 & 5131 & 1497 & 2369 & 1653 \\
\hline 2003 import & 5131 & 2369 & 2694 & 1653 & 3188 & 1497 \\
\hline 2004 export & 3565 & 3632 & 5394 & 1714 & 2602 & 1978 \\
\hline 2004 import & 5394 & 2602 & 3565 & 1978 & 3632 & 1714 \\
\hline 2005 export & 4160 & 3531 & 5376 & 1884 & 2955 & 2100 \\
\hline 2005 import & 5376 & 2955 & 4160 & 2100 & 3531 & 1884 \\
\hline 2006 export & 5600 & 3969 & 6485 & 2439 & 3432 & 2717 \\
\hline 2006 import & 6485 & 3432 & 5600 & 2717 & 3969 & 2439 \\
\hline 2007 export & 6411 & 3899 & 7939 & 3017 & 3911 & 3211 \\
\hline 2007 import & 7939 & 3911 & 6411 & 3211 & 3899 & 3017 \\
\hline 2008 export & 6708 & 3884 & 8932 & 3142 & 3916 & 3742 \\
\hline 2008 import & 8932 & 3916 & 6708 & 3742 & 3884 & 3142 \\
\hline
\end{tabular}

Table 2 | Carbon intensities of Italy, Poland, and Sweden during the period 2000-2008 ( $\mathrm{ktCO}_{2} \mathrm{e} / \mathrm{millions}$ of Euro).

\begin{tabular}{llcc}
\hline & Italy & Poland & Sweden \\
\hline 2000 & 0.40 & 2.03 & 0.10 \\
2001 & 0.38 & 1.74 & 0.12 \\
2002 & 0.36 & 1.70 & 0.11 \\
2003 & 0.37 & 1.91 & 0.11 \\
2004 & 0.35 & 1.78 & 0.12 \\
2005 & 0.34 & 1.48 & 0.11 \\
2006 & 0.31 & 1.37 & 0.10 \\
2007 & 0.31 & 1.20 & 0.09 \\
2008 & 0.29 & 0.99 & 0.09 \\
\hline
\end{tabular}

sets to calculate the values of carbon intensity for each of the three countries for the period 2000-2008 (Table 2).

In order to assess the net emissions embodied in Italy-PolandSweden trade, we computed the responsibility of $\mathrm{CO}_{2} \mathrm{e}$ embodied in our trilateral system trade as expressed in the theoretical framework. Table 3 presents net emissions relative to bilateral commercial relationships ${ }^{1}$.

The result is given by the difference between imported $\mathrm{CO}_{2} \mathrm{e}$ (given by the economic value of imported goods times the carbon intensity of the foreign producer) and exported $\mathrm{CO}_{2} \mathrm{e}$ (given by the economic value of exported goods time the carbon intensity of the country). When the value is positive, it means that

\footnotetext{
${ }^{1}$ The calculations reported in the table are based on the portion of Eqs 2-4 dealing
} with trade, that is, the last four terms on the right-hand side of these equations. 
Table 3 | Net emissions embodied in Italy-Poland-Sweden trade according to $\mathrm{NCl}$ method.

\begin{tabular}{|c|c|c|c|c|c|c|c|c|c|}
\hline & & Italy & & & Poland & & & Sweden & \\
\hline & $\begin{array}{l}\text { to-from } \\
\text { Poland } \\
\text { (A) } \\
{\left[-g_{\mathrm{i}} X_{\mathrm{ip}}+\right.} \\
\left.g_{\mathrm{p}} M_{\mathrm{pi}}\right]\end{array}$ & $\begin{array}{l}\text { to-from } \\
\text { Sweden } \\
\text { (B) } \\
{\left[-g_{\mathrm{i}} X_{\text {is }}+\right.} \\
\left.g_{\mathrm{s}} M_{\mathrm{si}}\right]\end{array}$ & $\begin{array}{l}\text { Carbon } \\
\text { transferred } \\
(A+B)\end{array}$ & $\begin{array}{l}\text { to-from } \\
\text { Italy } \\
\text { (C) } \\
{\left[-g_{\mathrm{p}} X_{\mathrm{pi}}+\right.} \\
\left.g_{\mathrm{i}} M_{\mathrm{ip}}\right]\end{array}$ & $\begin{array}{l}\text { to-from } \\
\text { Sweden } \\
\text { (D) } \\
{\left[-g_{\mathrm{p}} X_{\mathrm{ps}}+\right.} \\
\left.g_{\mathrm{s}} M_{\mathrm{sp}}\right]\end{array}$ & $\begin{array}{l}\text { Carbon } \\
\text { transferred } \\
\text { (C+D) }\end{array}$ & $\begin{array}{l}\text { to-from } \\
\text { Italy } \\
\text { (E) } \\
{\left[-g_{\mathrm{s}} X_{\mathrm{si}}+\right.} \\
\left.g_{\mathrm{i}} \mathrm{M}_{\mathrm{is}}\right]\end{array}$ & $\begin{array}{l}\text { to-from } \\
\text { Poland } \\
\text { (F) } \\
{\left[-g_{\mathrm{s}} X_{\mathrm{sp}}+\right.} \\
\left.g_{\mathrm{p}} M_{\mathrm{ps}}\right]\end{array}$ & $\begin{array}{l}\text { Carbon } \\
\text { transferred } \\
(E+F)\end{array}$ \\
\hline & $\mathrm{Kt} \mathrm{CO} \mathrm{CO}_{2}$ & $\mathrm{Kt} \mathrm{CO}_{2} \mathrm{e}$ & $\mathrm{Kt} \mathrm{CO}_{2} \mathrm{e}$ & $\mathrm{Kt} \mathrm{CO}_{2} \mathrm{e}$ & $\mathrm{Kt} \mathrm{CO} \mathrm{CO}_{2} \mathrm{e}$ & $\mathrm{Kt} \mathrm{CO}_{2} \mathrm{e}$ & $\mathrm{Kt} \mathrm{CO} \mathrm{CO}_{2}$ & $\mathrm{Kt} \mathrm{CO}_{2} \mathrm{e}$ & $\mathrm{Kt} \mathrm{CO} \mathrm{CO}_{2} \mathrm{e}$ \\
\hline 2000 & 8106 & -1.183 & 6922 & -8106 & -3082 & -11188 & 1183 & 3082 & 4265 \\
\hline 2001 & 7232 & -844 & 6388 & -7232 & -2277 & -9509 & 844 & 2277 & 3121 \\
\hline 2002 & 7443 & -832 & 6610 & -7443 & -2203 & -9646 & 832 & 2203 & 3036 \\
\hline 2003 & 8826 & -905 & 7921 & -8826 & -2678 & -11504 & 905 & 2678 & 3583 \\
\hline 2004 & 8368 & -972 & 7396 & -8368 & -2827 & -11196 & 972 & 2827 & 3800 \\
\hline 2005 & 6538 & -886 & 5652 & -6538 & -2565 & -9104 & 886 & 2565 & 3451 \\
\hline 2006 & 7120 & -899 & 6221 & -7120 & -3064 & -10184 & 899 & 3064 & 3964 \\
\hline 2007 & 7545 & -848 & 6697 & -7545 & -3325 & -10870 & 848 & 3325 & 4173 \\
\hline 2008 & 6955 & -763 & 6192 & -6955 & -2788 & -9744 & 763 & 2788 & 3552 \\
\hline Total (2000-2008) & 68134 & -8.134 & 60000 & -68134 & -24810 & -92944 & 8.134 & 24810 & 32944 \\
\hline Yearly average & 7570 & -904 & 6667 & -7570 & -2757 & -10327 & 904 & 2757 & 3660 \\
\hline
\end{tabular}

In Eqs 2-4 we associate country "a" to Italy (i), country "b" to Poland (p), and country "c" to Sweden (s).

with the proposed NCI method the country imports additional $\mathrm{CO}_{2}$ e emission responsibility from outside its boundaries; when the value is negative, the country transfers a portion of its $\mathrm{CO}_{2} \mathrm{e}$ emission responsibility elsewhere.

Our results indicate that, during the period 2000-2008, Italy has been responsible for additional $68134 \mathrm{kt}$ of $\mathrm{CO}_{2} \mathrm{e}$ embodied in all the goods imported from Poland, which equals to $7570 \mathrm{kt}$ of $\mathrm{CO}_{2} \mathrm{e} /$ year $\left(\mathrm{CO}_{2} \mathrm{e}\right.$ imported from Poland minus that exported to Poland). Conversely, by adopting our method Italy would transfer emission responsibility equal to $8134 \mathrm{kt}$ of $\mathrm{CO}_{2} \mathrm{e}$ exporting products to Sweden, corresponding to $904 \mathrm{kt} / \mathrm{year}$, on average. The opposite is true from the point of view of Poland and Sweden, respectively, in their commercial relationship with Italy. Sweden is also responsible for additional $24810 \mathrm{kt}$ of $\mathrm{CO}_{2} \mathrm{e}$, due to its trade with Poland $\left(2757 \mathrm{kt} / \mathrm{year}\right.$ of $\left.\mathrm{CO}_{2} \mathrm{e}\right)$. In general, negative figures are the counterpart of positive ones, because additional responsibility for a single country corresponds to a responsibility transfer from its commercial counterpart.

According to the NCI method, the aggregate 2000-2008 emissions trade balance for Italy, given by the algebraic sum of the annual contribution from commercial relationships with the other two countries, results in a net import of $60000 \mathrm{kt}$ of $\mathrm{CO}_{2} \mathrm{e}$; for Sweden it is 32944 kt $\mathrm{CO}_{2}$ e. Consequently, for Poland $92944 \mathrm{kt}$ $\mathrm{CO}_{2} \mathrm{e}$ are transferred to the other two countries. These values, that represent the carbon transferred by each nation in this trilateral scheme, should be added (or subtracted) to the results of the IPCC approach, which ascribes the emissions responsibility exclusively to the producer on the basis of where these are generated (geographical principle). In other words, according to Eqs 2-4, for every country, we should correct the results of the official GHG national inventory (Eurostat, 2011), by adding/subtracting the emission responsibility $\left(\mathrm{in}_{\mathrm{CO}_{2}} \mathrm{e}\right.$ ) due to trade (carbon transfer in Table 3). Table 4 compares the results obtained from IPCC inventory and NCI method for the three countries. We calculated that, on average, the results from a consumer perspective are higher than those of the IPCC inventory by about $1.4 \%$ for Italy $\left(R_{\mathrm{a}}\right.$ in Eq. 2$)$, and by about $11.88 \%$ for Sweden $\left(R_{\mathrm{c}}\right.$ in Eq. 4); indeed the NCI method would make Polish emissions lower than the national inventory level by about $2.81 \%$ $\left(R_{\mathrm{b}}\right.$ in Eq. 3).

Let us now consider a further application of the NCI method at the level of the single sector. In particular, a change in the import-export of goods in the class of machineries and transport equipment (MTE) among the three countries is hypothesized in order to evaluate the consequences of a possible change in trade partners induced by the adoption of the NCI method. The choice of this crucial sector is primarily due to its relevance in the international trade among the three countries, since it represents $46 \%$ of total exports from Poland to Italy and $45 \%$ of total exports from Sweden to Italy (Eurostat, 2011) ${ }^{2}$. Let us suppose that Italy shifts its imports of MTE from Poland to Sweden. The hypothetical unilateral decision of Italy to purchase MTE goods from Sweden instead of Poland would bring about a change also in emission responsibility assignment.

In 2008, Italians spent 4349 million Euro to purchase MTE from Poland (Eurostat, 2011). Let us suppose that this amount of money is completely spent to buy the same goods from Sweden. In terms of emission responsibility, Italy would be less charged than before, due to the difference in carbon intensity between Sweden and Poland; no relevant direct consequences would occur

\footnotetext{
${ }^{2}$ Products are classified according to the Combined Nomenclature (CN8), e.g. the
} aggregate MTE. 
Table 4 | Comparison between production-based accounting (IPCC inventory) and consumption-based accounting ( $\mathrm{NCl}$ method) and percentage variation between the two approaches.

\begin{tabular}{|c|c|c|c|c|c|c|c|c|c|}
\hline & \multicolumn{3}{|c|}{ Italy } & \multicolumn{3}{|c|}{ Poland } & \multicolumn{3}{|c|}{ Sweden } \\
\hline & IPCC & $\mathrm{NCl}$ & $\begin{array}{l}\text { Percentage } \\
\text { variation }(\%)\end{array}$ & IPCC & $\mathrm{NCl}$ & $\begin{array}{l}\text { Percentage } \\
\text { variation (\%) }\end{array}$ & IPCC & $\mathrm{NCl}$ & $\begin{array}{l}\text { Percentage } \\
\text { variation (\%) }\end{array}$ \\
\hline & Inventory & $\boldsymbol{R}_{\mathbf{i}}$ & & Inventory & $\mathbf{R}_{\mathbf{p}}$ & & Inventory & $\mathbf{R}_{\mathbf{s}}$ & \\
\hline & I.P.C.C DE & $\mathrm{DE}_{\mathrm{i}}+$ column 4 & & I.P.C.C. DE & $\mathrm{DE}_{p}+$ column 7 & & I.P.C.C. DE $\mathrm{DS}_{\mathrm{s}}$ & $\mathrm{DE}_{\mathrm{s}}+$ column 10 & \\
\hline & $\mathrm{Kt} \mathrm{CO} 2 \mathrm{e}$ & $\mathrm{Kt} \mathrm{CO}_{2} \mathrm{e}$ & & $\mathrm{Kt} \mathrm{CO}_{2} \mathrm{e}$ & $\mathrm{Kt} \mathrm{CO} 2 \mathrm{e}$ & & $\mathrm{Kt} \mathrm{CO}_{2} \mathrm{e}$ & $\mathrm{Kt} \mathrm{CO}_{2} \mathrm{e}$ & \\
\hline 2000 & 472,749 & 479,671 & 1.46 & 376.704 & 365.516 & -2.97 & 27.925 & 32.190 & 15.27 \\
\hline 2001 & 470,567 & 476,955 & 1.36 & 370.057 & 360.548 & -2.57 & 30.798 & 33.919 & 10.13 \\
\hline 2002 & 465,836 & 472,446 & 1.42 & 356.135 & 346.489 & -2.71 & 29.349 & 32.385 & 10.34 \\
\hline 2003 & 489,859 & 497,780 & 1.62 & 366.568 & 355.064 & -3.14 & 31.148 & 34.731 & 11.50 \\
\hline 2004 & 488,628 & 496,024 & 1.51 & 364.232 & 353.036 & -3.07 & 33.959 & 37.759 & 11.19 \\
\hline 2005 & 484,351 & 490,003 & 1.17 & 361.356 & 352.252 & -2.52 & 31.347 & 34.798 & 11.01 \\
\hline 2006 & 466,947 & 473,168 & 1.33 & 372.589 & 362.405 & -2.73 & 32.294 & 36.258 & 12.27 \\
\hline 2007 & 481,259 & 487,956 & 1.39 & 373.735 & 362.865 & -2.91 & 31.598 & 35.771 & 13.21 \\
\hline 2008 & 448,921 & 455,113 & 1.38 & 360.866 & 351.122 & -2.70 & 29.691 & 33.243 & 11.96 \\
\hline Yearly & & & 1.40 & & & -2.81 & & & 11.88 \\
\hline average & & & & & & & & & \\
\hline
\end{tabular}

In Eqs 2-4, we associate " $R_{a}$ " to Italy $\left(R_{i}\right)$, " $R_{b}$ " to Poland $\left(R_{p}\right)$, and " $R_{c}$ " to Sweden $\left(R_{s}\right)$.

in emission responsibility for Poland and Sweden as long as they adequate the production level to the new market conditions. In fact, Poland would not produce MTE not requested by Italy any longer so that it would not emit GHGs to produce and export goods, while Sweden would export the additional GHG emissions related to additional goods produced within the country and now requested by Italy. In other words, the net effect of the shift of the Italian imports from Poland to Sweden can be considered equal to zero for the latter two countries ${ }^{3}$. At the same time, from an economic point of view, Poland would not export goods to Italy any longer, while Sweden accounts for a corresponding amount of additional exports.

We can easily compute the variation in the Italian emissions responsibility deriving from this hypothetical shift in its imports of MTE from one country to another.

We know from Table 4 that in 2008: $R_{\mathrm{i}}=455,113 \mathrm{kt} \mathrm{CO}_{2} \mathrm{e}$. According to our hypothesis, Italy does not import MTE from Poland any longer, which implies a responsibility subtraction equal to: $4349 \mathrm{mln} € \times 0.99 \mathrm{kt} \mathrm{CO}_{2} \mathrm{e} / \mathrm{mln} €=4305.51 \mathrm{kt}$ $\mathrm{CO}_{2}$ e. At the same time, Italy imports MTE from Sweden, with and additional responsibility equal to: $4349 \mathrm{mln} € \times 0.09 \mathrm{kt}$

\footnotetext{
${ }^{3}$ Different results would emerge as to the Polish and Swedish emissions responsibility, if we assumed that Poland and Sweden reacted to the new market conditions by modifying their stocks. Thus, for instance, Sweden could meet the higher Italian demand of its MTE by reducing its stocks (corresponding to emissions already produced that are now transferred to another country); similarly, Poland could increase its stocks of MTE as a consequence of the lower Italian demand. This would increase the Polish emission responsibility as the emissions embodied in the Polish MTE are no longer transferred elsewhere. In what follows, we will exclude this case for the sake of simplicity and assume that both countries can immediately adequate their production levels to the change in the Italian import flows.
}

$\mathrm{CO}_{2} \mathrm{e} / \mathrm{mln} €=391.41 \mathrm{kt} \mathrm{CO}_{2} \mathrm{e}$. The new responsibility assignment for Italy would then be:

$$
R_{i}^{*}=455,113-4305.51+391.41=451,198.9 \mathrm{kt} \mathrm{CO}_{2} \mathrm{e} .
$$

In this case, therefore, by shifting its MTE imports from Poland to Sweden, Italy would decrease its emissions responsibility by $3914.1 \mathrm{kt} \mathrm{CO}_{2} \mathrm{e}(=4305.51+391.41)$, that is $0.86 \%$, with respect to the case of no change in trade partner.

As in Eq. 5, in which both carbon intensity and import differentials are equally important, we obtain a benefit in terms of $\mathrm{CO}_{2}$ emissions whenever the difference in carbon intensity offsets the import differentials in monetary terms. A country, therefore, will have a reduction in its emissions whenever its import differential does not change (as in our example) or it increases less than the relative difference between the carbon intensity of its trading partners.

\section{DISCUSSION}

The NCI method (Caro et al., 2014) assigns to each country the import-related emissions and removes the export-related ones. Emissions imputed are calculated as the product of the economic value of traded goods times the carbon intensity of the producer nation. Therefore, on the one hand, an importer nation will be encouraged to find producers with the best environmental performances; on the other hand, exporter nations will be encouraged to reduce their carbon intensity to meet the higher demand for less polluting goods that may derive from the adoption of the NCI method. International trade is characterized not only by the flow of capital and goods, but also by the energy and emissions embodied in goods during their production (Pan et al., 2008). Giving responsibility to consumer countries in international trade 
could induce all the subjects involved in commercial dynamics to improve their environmental performances. If one nation were charged for the emissions embodied in goods imported from a higher carbon intensity country, it would be induced to find a more efficient exporter (with lower carbon intensity) in order to reduce its responsibility. At the same time, if a higher carbon intensity country wanted to maintain its commercial relationships with the other countries, it should decrease its carbon intensity. In our example, if Italy were overburdened by the emissions embodied in goods imported from Poland, it would be prompted to find a more efficient exporter in order to decrease its responsibility. At the same time, if Poland wanted to preserve its commercial relationships with Sweden and Italy, it should reduce its carbon intensity.

Assuming a NCI method viewpoint, consumers should take responsibility for choosing the best strategies and policy by showing a preference for producers, who are attentive to GHG reductions. However, as stated by Bastianoni et al. (2004), producers are not motivated to reduce emissions but indirectly. In other words, the effects of adopting a consumer perspective scheme to account for emission responsibility depend on how much consumers influence producer with their choices. To make this measure effective, a combination of environmental consciousness, economic convenience, and appropriate policies should be taken into consideration.

In this practical application (Figure 1), the adoption of NCI method would result in lower emission responsibility for the country with highest carbon intensity (Poland), because it exports goods with high carbon content (per Euro), thus transferring emission responsibility elsewhere, and imports goods with low carbon content of which it becomes responsible.

The representation of the country "a" decision to shift from country "b" to country "c" goods contributes to predict the possible consequences of a NCI method in a lapse of time. In our application, the first effect is that Italy would cut its emission responsibility; secondly, Sweden would become a more competitive producer due to the lower carbon embodied in its goods, and this might result in an increase in GDP, while Poland would have its competitiveness and export capacity (and GDP) reduced. The economic advantage for more efficient countries might more than offset the initial condition of being charged of more emission responsibility than in the case of production-based accounting (Figure 1). Finally, Poland would be induced to improve its production processes and efficiency. This new situation may bring about a progressive improvement in production processes aimed at reducing carbon embodied in products and, ultimately, a global reduction of actual $\mathrm{CO}_{2}$ emissions in the atmosphere.

A further implication can be hypothesized: we can suppose that in order to improve their production efficiency, higher carbon intensity countries could plan to import high technology (in the form of final goods, patents, or simply information) from lower carbon intensity ones. This might result in a "win-win" situation for all countries, as it would satisfy higher carbon intensity country environmental necessities to lower its carbon intensity, while benefiting lower carbon intensity country economies by increasing their exports of technological devices. The higher carbon intensity country imports of clean technologies could also contribute, in the medium run, to restore their market share while stimulating improvements in high technology and emissions reduction in all countries. However, technological expertise and carbon intensity of different countries may not necessarily converge to a common level because more developed economies will always have an incentive to maintain their leadership in industrial efficiency and take economic advantage of this. In general we believe that, in order to solicit adequate incentives and policies for the reduction of climate change in developed and developing countries, the use of a systemic approach to allocate emissions due to international trade in IPCC inventories is crucial.

The advantage of this particular method with respect to the consumer-based accounting characterizing the EEIO analyses is that it is very easy to implement and no further data are needed

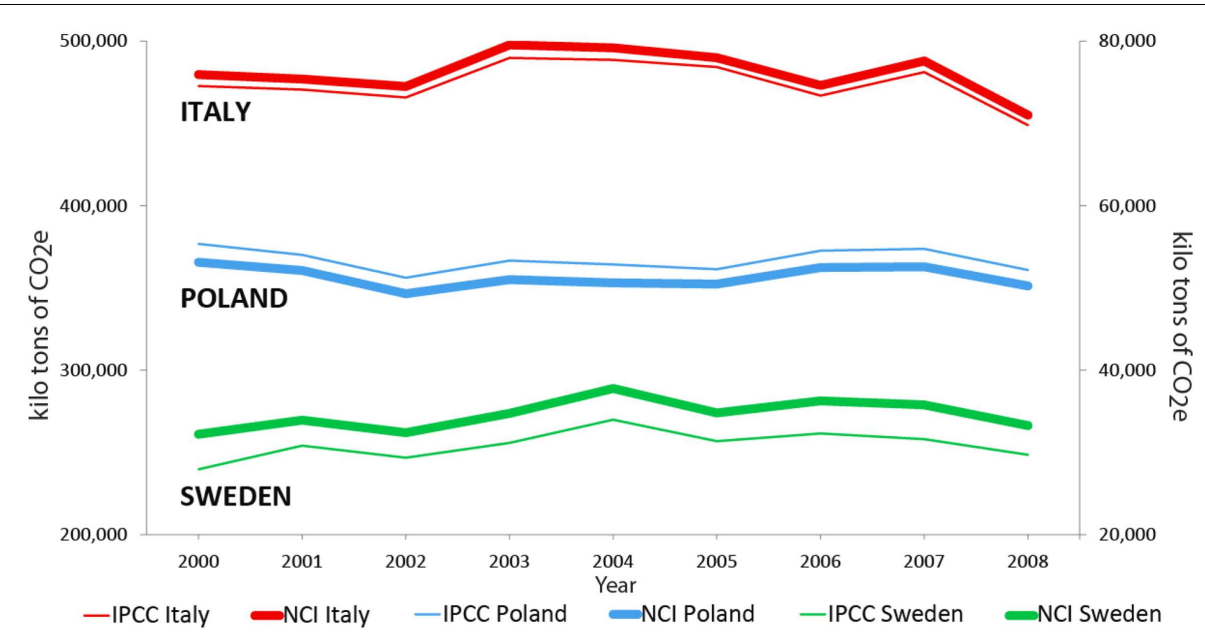

FIGURE 1 | Comparison between production-based accounting (IPCC) and consumption-based accounting (NCI method) in the annual inventories of Italy, Poland (left axis), and Sweden (right axis) 
than those that are already estimated at the national level. In fact, all we need are the bilateral import/export flows and the carbon intensity of each country, both of which are easily and readily available from many sources. In the case of the EEIO, instead, the quality and quantity of data required are much higher since sectorial information on flows and carbon intensities are needed. The use of indicators (carbon intensity) as tools to evaluate changes in emission responsibility adopted in our approach can be a less detailed but more practical way to obtain adequate advantages and to generate significant policy implications than a consumer perspective obtained through direct and punctual measures (such as the EEIO). It might not be the "ideal" solution, but in our opinion it is more suitable than the present one (IPCC guidelines) to reduce global emissions and it can represent a relevant step toward the consumer perspective (EEIO models), in terms of practical and political feasibility.

\section{CONCLUSION}

This paper highlights the problems related to the national GHG inventory approach (IPCC - Intergovernmental Panel on Climate Change, 2006) to estimate emissions embodied in international trade and it applies the NCI method - a theoretical framework recently proposed by Caro et al. (2014) - in order to allocate emission responsibility according to a consumer perspective.

The NCI method adopts a consumer perspective but at the same time it does not replace the current method to estimate national emissions (IPCC), of which it can be considered as a complement. Although the exercise analyzed here is admittedly based on simplistic assumptions, it can provide some interesting insights on the possible implications of adopting a consumptionbased accounting that can be easily extended to examine a larger set of countries and different regional aggregation levels. Since the production-based accounting is already calculated for each country that joined the Kyoto Protocol, applying the NCI method is not difficult. In fact, the data that are needed to apply our approach are widely available. The adoption of a consumer perspective would have deep consequences on the global trading system as well as on the international environmental policies aimed at reducing $\mathrm{CO}_{2}$ emissions. Thus, for instance, it could imply a deep revision of the Emission Trading System proposed by the Kyoto Protocol to cut global carbon emissions. In a consumer perspective, Annex I countries would probably end up with higher emissions responsibility and thus also higher carbon abatement targets with respect to the present production-based accounting. This might lead industrialized countries to increase their demand of tradable permits, with a consequent change in carbon prices and an overall reallocation of tradable permits among participating countries. As shown by the simple theoretical exercise developed here, moreover, the consumer perspective is likely to lead not only to a revision of countries' responsibility with respect to the producer perspective, but also to a consequent change in the trading flows that would further modify the allocation of the emissions responsibility.

In our opinion, the main and ultimate target of the accounting system proposed in this paper should be to generate a trade framework in which countries take binding commitments as a part of a group instead as a individual entities so that the impacts of trade and global emissions can be acceptably reduced. Although, a deeper analysis of this issue goes beyond the scope of the present paper, this work intends to move a first step in this direction and thus promote future discussion on possible applications and policy implications of the consumption-based accounting.

\section{ACKNOWLEDGMENTS}

The authors would like to thank two anonymous referees as well as the participants to the Workshop "e-Frame Environmental Indicators" (Fondazione ENI Enrico Mattei, Venice, 5-6 December 2013) for useful comments and suggestions. The usual disclaimer applies. Simone Borghesi gratefully acknowledges financial support by MIUR (Italian Ministry of Education, University and Research) for the PRIN 2010-2011 National Research Project (prot. 2010S2LHSE).

\section{REFERENCES}

Andersen, O., Gossling, S., Simonsen, M., Walnum, H., Peeters, P., and Neiberger, C. (2010). $\mathrm{CO}_{2}$ emissions from the transport of China's exported goods. Energy Policy 38, 5790-5798. doi:10.1016/j.enpol.2010.05.030

Andrew, F., and Forgie, V. (2008). A three-perspective view of greenhouse gas emission responsibility in New Zealand. Ecol. Econ. 68, 194-204. doi:10.1016/ j.ecolecon.2008.02.016

Baer, P., Harte, J., Haya, B., Herzog, A., Holdren, J., Hultman, N., et al. (2000). Equity and greenhouse responsibility. Science 289, 2287. doi:10.1073/pnas.1203282109

Bastianoni, S., Pulselli, F. M., and Tiezzi, E. (2004). The problem of assigning responsibility for greenhouse gas emissions. Ecol. Econ. 49, 253-257. doi:10.1016/j. ecolecon.2004.01.018

Caro, D., Bastianoni, S., Borghesi, S., and Pulselli, F. M. (2014). On the feasibility of a consumer-based allocation method in national GHG inventories. Ecol. Indicat. 36, 640-643. doi:10.1016/j.ecolind.2013.09.021

Davis, S., and Caldeira, K. (2010). Consumption-based accounting of $\mathrm{CO}_{2}$ emissions. Sustain. Sci. 107, 5687-5692. doi:10.1073/pnas.0906974107

Davis, S. J., Peters, G. P., and Caldeira, K. (2011). The supply chain of $\mathrm{CO}_{2}$ emissions. Proc. Natl. Acad. Sci. U.S.A. 108, 18554-18559. doi:10.1073/pnas.1107409108

Eurostat. (2011). Statistic database. Available from: http://epp.eurostat.ec.europa. eu/portal/page/portal/statistics/search_database

Ferng, J. (2003). Allocating the responsibility of $\mathrm{CO}_{2}$ over-emissions from the perspectives of benefit principle and ecological deficit. Ecol. Econ. 46, 121-141. doi:10.1016/S0921-8009(03)00104-6

Gupta, S., and Bhandari, P. (1999). An effective allocation criterion for $\mathrm{CO}_{2}$ emissions. Energy Policy 27, 727-736. doi:10.1016/S0301-4215(99)00058-0

IPCC - Intergovernmental Panel on Climate Change. (2006). 2006 IPCC Guideline for National Greenhouse Gas Inventories, eds H. S. Eggleston, L. Buendia, K. Miwa, T. Ngara, and K. Tanabe (Tokyo: IGES).

Lenzen, M., Kanemoto, K., Moran, D., and Geschke, A. (2012). Mapping the structure of the world economy. Environ. Sci. Technol. 46, 8374-8381. doi:10.1021/ es300171x

Lenzen, M., Murray, J., Sack, F., and Wiedemann, T. (2007). Shared producer and consumer responsibility: theory and practice. Ecol. Econ. 61, 27-42. doi:10.1016/ j.ecolecon.2006.05.018

Li, Y., and Hewitt, C. (2008). The effect of trade between China and the UK on national and global carbon dioxide emissions. Energy Policy 36, 1907-1914. doi:10.1016/j.enpol.2008.02.005

Munksgaard, J., and Pedersen, A. (2001). $\mathrm{CO}_{2}$ accounts for open economies: producer or consumer responsibility? Energy Policy 29, 327-334. doi:10.1016/S03014215(00)00120-8

Pan, J., Phillips, J., and Chen, Y. (2008). China's balance of emissions embodied in trade: approach to measurement and allocating international responsibility. Oxf. Rev. Econ. Pol. 24, 354-376. doi:10.1093/oxrep/grn016

Peters, G., and Hertwich, E. (2008). Post-Kyoto greenhouse gas inventories: production versus consumption. Climate Change 86, 51-66. doi:10.1007/s10584-0079280- 1

Proops, L. R., Atkinson, G., Schlotheim, B., and Simon, S. (1999). International trade and sustainability footprint: a practical criterion for its assessment. Ecol. Econ. 28, 75-97. doi:10.1016/S0921-8009(98)00030-5 
Rodrigues, J., and Domingos, T. (2008). Consumer and producer environmental responsibility: comparing two approaches. Ecol. Econ. 66, 533-546. doi:10.1016/ j.ecolecon.2007.12.010

Rodrigues, J., Domingos, T., Giljum, S., and Schneider, F. (2006). Designing an indicator of environmental responsibility. Ecol. Econ. 59, 256-266. doi:10.1016/j. compbiomed.2010.04.002

Shui, B., and Harris, C. (2006). The role of $\mathrm{CO}_{2}$ embodiment in US-China trade. Energy Policy 34, 4063-4068. doi:10.1016/j.enpol.2005.09.010

$\mathrm{Su}, \mathrm{B}$., Ang, B. W., and Low, M. (2013). Input-output analysis of $\mathrm{CO}_{2}$ emissions embodied in trade and the driving forces: processing and normal exports. Ecol. Econ. 88, 119-125. doi:10.1016/j.ecolecon.2013.01.017

Wiedmann, T. (2009). A review of recent multi-region input-output models used for consumption-based emission and resource accounting. Ecol. Econ. 69, 211-222. doi:10.1016/j.ecolecon.2009.08.026

Wiedmann, T. O., Wilting, H. C., Lenzen, M., Lutter, S., and Palm, V. (2011). Quo vadis MRIO? Methodological, data and institutional requirements for MultiRegion Input-Output analysis. Ecol. Econ. 70, 1937-1945. doi:10.1016/j.ecolecon. 2011.06.014

Zaks, D. P. M., Barford, C., Ramankutty, N., and Foley, A. (2009). Producer and consumer responsibility for greenhouse gas emissions from agricultural production: a perspective for the Brazilian Amazon. Environ. Res. Lett. 4, 044010. doi:10.1088/1748-9326/4/4/044010
Zhang, Z. X. (2011). Assessing China's carbon intensity pledge for 2020: stringency and credibility issues and their implications. Environ. Econ. Pol. Stud. 13, 219-235. doi:10.1007/s10018-011-0012-4

Conflict of Interest Statement: The authors declare that the research was conducted in the absence of any commercial or financial relationships that could be construed as a potential conflict of interest.

Received: 18 October 2013; accepted: 13 January 2014; published online: 27 January 2014.

Citation: Bastianoni S, Caro D, Borghesi S and Pulselli FM (2014) The effect of a consumption-based accounting method in national GHG inventories: a trilateral trade system application. Front. Energy Res. 2:4. doi: 10.3389/fenrg.2014.00004

This article was submitted to Energy Systems and Policy, a section of the journal Frontiers in Energy Research.

Copyright (c) 2014 Bastianoni, Caro, Borghesi and Pulselli. This is an open-access article distributed under the terms of the Creative Commons Attribution License (CC $B Y)$. The use, distribution or reproduction in other forums is permitted, provided the original author(s) or licensor are credited and that the original publication in this journal is cited, in accordance with accepted academic practice. No use, distribution or reproduction is permitted which does not comply with these terms. 